\title{
Correction: Self-medication with antibiotics in Maputo, Mozambique: practices, rationales and relationships
}

Carla F. Rodrigues (D)

Correction to: Palgrave Communications https://doi.org/10.1057/s41599-019-0385-8, published online 14 January 2020.

The legend for Fig. 1 did not state the correct copyright status of the photograph depicted.

The original stated: 'Home pharmacy' in Maputo (city centre), displaying the combination of medicines available in the household. Photograph taken by the author.

The amended version states: 'Home pharmacy' in Maputo (city centre), displaying a combination of medicines available in the household. This figure is not covered by the Creative Commons Attribution 4.0 International License. Copyright (C) Carla Rodrigues, all rights reserved.

This has now been corrected in the published paper.

Published online: 06 February 2020

\footnotetext{
(c) (i) Open Access This article is licensed under a Creative Commons Attribution 4.0 International License, which permits use, sharing, adaptation, distribution and reproduction in any medium or format, as long as you give appropriate credit to the original author(s) and the source, provide a link to the Creative Commons license, and indicate if changes were made. The images or other third party material in this article are included in the article's Creative Commons license, unless indicated otherwise in a credit line to the material. If material is not included in the article's Creative Commons license and your intended use is not permitted by statutory regulation or exceeds the permitted use, you will need to obtain permission directly from the copyright holder. To view a copy of this license, visit http://creativecommons.org/licenses/by/4.0/.
}

(C) The Author(s) 2020 